\title{
SISTEM KULTUR SEMIKONTINU DALAM PRODUKSI LIPID DAN PENYISIHAN COD MENGGUNAKAN KONSORSIUM MIKROALGA DARI PALM OIL MILL EFFLUENT (POME)
}

\author{
Shinta Elystia ${ }^{1}$, Tria Bela Novira ${ }^{1}$, Sri Rezeki Muria ${ }^{2}$ \\ 1Program Studi Teknik Lingkungan, Fakultas Teknik, Universitas Riau \\ Kampus Bina Widya Km. 12,5 Simpang Baru Pekanbaru \\ 2Jurusan Teknik Kimia, Fakultas Teknik Universitas Riau Kampus Bina \\ Widya Km. 12,5 Simpang Baru Pekanbaru \\ e-mail: shintaelystia@yahoo.com, triabelanoviraa@gmail.com, \\ sri_muria@gmail.com
}

\begin{abstract}
Abstrak
Penggunaan energi sebagian besar masih berasal dari sumber energi tidak terbarukan yang jumlahnya semakin berkurang. Produksi biofuel dari kadar lipid dalam biomassa konsorsium mikroalga dapat menjadi salah satu energi alternatif dalam menghasilkan energi terbarukan. Palm Oil Mill Effluent (POME) mengandung bahan organik yang dapat menjadi sumber nutrisi untuk pertumbuhan konsorsium mikroalga seiring terjadinya penyisihan COD pada air limbah. Produktivitas biomassa dan kadar lipid akan meningkat setelah dilakukan pergantian limbah sebagai penambahan nutrisi pada medium kultur. Penelitian ini bertujuan untuk mengetahui pertumbuhan konsorsium mikroalga, kadar lipid yang dihasilkan, serta efisiensi penyisihan COD pada POME. Kultivasi dilakukan dengan mengganti setengah volume kultur dengan fresh POME pada periode pergantian limbah setiap 3, 4, dan 6 hari selama 12 hari kultivasi. Hasil penelitian menunjukkan kondisi kultivasi terbaik terdapat pada pergantian limbah setiap 6 hari dengan kerapatan sel mikroalga $1,01 \times 10^{7} \mathrm{sel} / \mathrm{ml}$, kadar lipid 19,33\%, serta efisiensi penyisihan COD $81,25 \%$. Dari hasil penelitian dapat disimpulkan bahwa sistem semikontinu dengan adanya pergantian limbah dapat meningkatkan kerapatan sel mikroalga karena nutrisi dalam medium kultur terpenuhi, sehingga kadar lipid dan efisiensi penyisihan COD yang dihasilkan akan semakin meningkat.
\end{abstract}

Kata Kunci : Konsorsium Mikroalga, Palm Oil Mill Effluent (POME), Periode Pergantian Limbah, Kadar Lipid, COD

\begin{abstract}
Energy use mostly comes from non-renewable energy sources that gradually decreased. Biofuel production from lipid content in the biomass of microalgae consortium can be one of the alternative energies in producing renewable energy. Palm Oil Mill Effluent (POME) contains organic material that can be a nutrient source for microalgae consortium growth along with COD removal in wastewater. Biomass productivity and lipid content will increase after the replacement as an addition of nutrients to the culture medium. The aim of this research to determine the growth microalgae consortium, lipid content that produced, and efficiency of COD removal in POME. The microalgae consortium was cultivated by replacing half volume of culture with fresh POME in period every 3, 4, and 6 days for 12 days of cultivation. The result showed the best cultivation condition was every 6 days replacement period which cell density $1,01 \times 10^{7} \mathrm{cell} / \mathrm{s} / \mathrm{ml}$, lipid content 19,33\%, and efficiency of COD removal $81,25 \%$. The results of the study can be concluded that the semicontinuous system with the replacement can increase the cell density of microalgae because the nutrients in culture are being fulfilled, as well as lipid content and the efficiency of COD removal will increase.
\end{abstract}

Keywords: Microalgae consortium, Palm Oil Mill Effluent (POME), Replacement period, Lipid content, $C O D$ 


\section{PENDAHULUAN}

Penggunaan energi menjadi suatu kebutuhan yang sangat penting bagi kelangsungan hidup manusia dan meningkat seiring dengan pertumbuhan ekonomi serta pertambahan penduduk. Pertumbuhan konsumsi energi di Indonesia pada tahun 2016 mengalami peningkatan sebesar 4,7\%. Berdasarkan total energi yang digunakan, Indonesia masih bergantung pada energi fosil yang terdiri dari minyak bumi $42,3 \%$, batu bara $34,8 \%$, gas alam $19,8 \%$, hidro $1,9 \%$, sedangkan energi terbarukan hanya sebesar 1,3\% (BPS, 2017). Ketergantungan terhadap energi fosil yang relatif cukup tinggi dapat menimbulkan permasalahan diantaranya menipisnya cadangan energi fosil, emisi gas rumah kaca akibat pembakaran energi fosil dan kerusakan lingkungan, sehingga diperlukan adanya sumber daya energi alternatif yang dapat menggantikan penggunaan bahan bakar fosil (Cheah dkk, 2016). Produksi biofuel dari mikroorganisme fotosintesis menjadi salah satu proses dalam menghasilkan energi terbarukan serta mitigasi terhadap pemanasan global (Spolaore dkk, 2006).

Mikroalga merupakan mikroorganisme yang dapat menjadi sumber energi terbarukan karena adanya mekanisme yang mengubah energi matahari menjadi energi kimia melalui fiksasi $\mathrm{CO}_{2}$ dalam menghasilkan biomassa (Mata dkk, 2010). Mikroalga mampu menghasilkan kadar lipid lebih dari 50\% (dalam biomassa kering) yang dapat dikonversi menjadi bahan baku biofuel (Hossain dkk, 2008), dan memproduksi energi 20-100 kali lipat lebih tinggi dibandingkan dengan tumbuhan tingkat tinggi lainnya (Chisti, 2007). Dalam pertumbuhannya mikroalga membutuhkan nutrisi yang cukup, salah satunya dengan memanfaatkan kandungan organik atau anorganik yang terdapat dalam air limbah seiring terjadinya penyisihan polutan pada air limbah (Abomohra dkk, 2016).

Budianta (2005) menyatakan Palm Oil Mill Effluent (POME) mengandung N, P, K, yang dapat menjadi sumber nutrisi untuk tumbuhan. POME pada kolam IV PT. X memiliki karakteristik kadar COD 3.228 mg/l, karbon (C) 278,1 mg/l, Nitrogen (N) 49,69 $\mathrm{mg} / \mathrm{l}$, dan Fosfor $(\mathrm{P}) 2,879 \mathrm{mg} / \mathrm{l}$ dengan rasio
C: $N: P=96,6: 17,3: 1$ (PT. X, 2019). Rasio nutrisi yang dibutuhkan oleh mikroalga yaitu $\mathrm{C}: \mathrm{N}: \mathrm{P}=56: 9$ : 1 (Mahdi dkk, 2012). Oleh karena itu, POME pada kolam IV memenuhi kebutuhan nutrisi mikroalga sehingga berpotensi sebagai medium untuk pertumbuhannya. Hal ini ditandai dengan adanya pertumbuhan konsorsium mikroalga pada kolam tersebut.

Kultur konsorsium mikroalga memiliki pertumbuhan yang lebih cepat dan biomassa yang lebih tinggi dibandingkan dengan monokultur, dengan adanya pertumbuhan biomassa yang tinggi akan menghasilkan kadar lipid yang tinggi pula (Woertz dkk, 2009). Menurut Kim dkk (2014), konsorsium mikroalga tidak hanya memiliki potensi bioenergi, tetapi juga dapat menyisihkan nutrisi pada air limbah. Hena dkk (2015), mendapatkan hasil penelitian bahwa konsorsium mikroalga indigeneous menunjukkan pertumbuhan dan stabilitas yang lebih baik dibandingkan dengan monokultur mikroalga, serta dapat menyisihkan COD lebih dari $98 \%$ pada air limbah susu. Kadar COD pada air limbah berkurang seiring dengan adanya aktivitas mikroalga yang menghasilkan oksigen dari proses fotosintesis (Hadiyanto, 2012).

Pada penelitian ini digunakan teknik kultur semikontinu yang dilakukan dengan adanya pergantian kultur oleh nutrien yang baru dalam periode waktu tertentu. Produktivitas biomassa akan meningkat seiring dengan adanya rasio nutrisi yang ditambahkan ke dalam kultur mikroalga (Yang dkk, 2017). Suantika dkk (2009), menyatakan bahwa teknik kultur semikontinu mampu meningkatkan produksi biomassa sebesar $38,5 \%$ dengan hasil biomassa sebesar $7,51 \pm 0,22 \mathrm{gr}$, sedangkan kultur batch sebesar 6,53 $\pm 0,16$ gr.

Dalam penelitian ini akan diteliti proses kultivasi yang terbaik dalam pertumbuhan konsorsium mikroalga dari POME menggunakan sistem semikontinu, dengan adanya pergantian limbah untuk menghasilkan kadar lipid yang tinggi sebagai bahan baku biofuel serta proses penyisihan COD pada POME. 


\section{METODOLOGI PENELITIAN}

1. Konsorsium Mikroalga dan Medium

Kultivasi

Konsorsium mikroalga indigeneous dan

POME yang digunakan berasal dari kolam IV pembuangan limbah cair PT. X. Konsorsium mikroalga diambil menggunakan plankton net berukuran 30-50 $\mu$, kemudian dilakukan identifikasi jenis mikroalga yang terdapat didalam POME. POME untuk medium pertumbuhan diambil dengan metode grab sampling dan kemudian disaring untuk menyisihkan partikel yang dapat mengganggu pertumbuhan konsorsium mikroalga. Selanjutnya dilakukan uji karakteristik awal kadar COD.



Gambar 1. Perspektif Instalasi Flat-Fotobioreaktor

\section{Pembiakan Kultur Konsorsium Mikroalga}

Konsorsium mikroalga diperbanyak dalam medium POME dan Bold Bassal Medium (BBM). $400 \mathrm{ml}$ konsorsium mikroalga dibiakkan dalam $3.240 \mathrm{ml}$ POME dan $360 \mathrm{ml}$ Bold Bassal Medium (BBM) sampai kepadatan sel $10^{6} \mathrm{sel} / \mathrm{ml}$ serta diberi aerasi secara kontinu.

\section{Kultivasi Konsorsium Mikroalga}

Kultivasi dilakukan dalam flatfotobioreaktor sebanyak 4 unit dengan dimensi $25 \times 8 \times 35 \mathrm{~cm}$ yang didesain berbahan kaca dan dilengkapi kran. Volume kerja total sebesar 5 liter dengan rasio POME dan konsorsium mikroalga $75: 25$ $(\%, v / v)$. Selama sistem kultur semikontinu, $50 \%$ volume kultur diganti dengan fresh POME pada periode pergantian limbah setiap 3, 4, dan 6 hari pada masing-masing flat-fotobioreaktor. Variabel kontrol dilakukan dengan sistem batch atau tanpa pergantian limbah. Waktu kultivasi dilakukan selama 12 hari. Untuk mengontakkan konsorsium mikroalga dan medium kultur digunakan aerator dengan debit udara $3 \mathrm{l} /$ menit. Flat-fotobioreaktor diletakkan diluar ruangan yang dilindungi atap dengan sumber cahaya berasal dari cahaya matahari.

\section{Analisis Kerapatan Sel Mikroalga}

Perhitungan kerapatan sel mikroalga dilakukan setiap 24 jam dimulai dari hari ke0 hingga hari ke-12. Sebanyak $1 \mathrm{ml}$ kultur mikroalga diambil dari tiap perlakuan. Kerapatan sel mikroalga dihitung menggunakan thomacytometer yang diamati dibawah mikroskop. Perhitungan kerapatan sel mikroalga menggunakan persamaan berikut (Bastidas, 2008) :

$\mathrm{N}=\mathrm{n} \times 10^{4}$

Keterangan:

$\mathrm{N}=$ Kerapatan sel $(\mathrm{sel} / \mathrm{ml})$

$\mathrm{n}=$ Jumlah sel dalam kotak (sel)

$10^{4}=$ Volume kotakan thomacytometer $(\mathrm{ml})$

\section{Analisis Kadar Lipid}

Analisis kadar lipid diawali dengan pengujian berat kering sampel. Sampel disaring menggunakan kertas saring dan dipanaskan pada suhu $105^{\circ} \mathrm{C}$. Ekstraksi lipid dilakukan dengan metode Bligh-Dyer. Lipid diekstraksi dengan larutan kloroform metanol $(2: 1, \quad \mathrm{v} / \mathrm{v})$ sehingga terpisah menjadi lapisan cairan kloroform dan metanol. Kemudian tambahkan metanol dan aquades untuk menghasilkan rasio 
pelarut akhir dari kloroform: metanol: aquades sebesar 1:1:0,9. Lapisan kloroform dicuci dengan $20 \mathrm{ml}$ larutan $\mathrm{NaCl} 5 \%$ dan diuapkan hingga kering. Total lipid ditentukan secara gravimetri (Putri dkk, 2011). Total lipid dapat dihitung dengan persamaan berikut:

Total lipid $(\%)=\frac{\mathrm{Lw}}{\mathrm{Bw}} \times 100 \%$

Keterangan:

Lw = Bobot lipid (gram)

$\mathrm{Bw}=$ Biomassa (gram)

\section{Analisis Kadar Chemical Oxygen Demand (COD)}

Sebanyak 2,5 $\mathrm{ml}$ sampel dimasukkan kedalam tabung reaksi dan ditambahkan $1,5 \mathrm{ml}$ larutan $\mathrm{K}_{2} \mathrm{Cr}_{2} \mathrm{O}_{7} 0,25 \mathrm{M}$, kemudian sedikit demi sedikit ditambahkan $3,5 \mathrm{ml}$ $\mathrm{H}_{2} \mathrm{SO}_{4}-\mathrm{AgSO}_{4}$. Tabung reaksi ditutup dan dikocok perlahan hingga homogen. Sampel kemudian dipanaskan selama 2 jam pada suhu $150{ }^{\circ} \mathrm{C}$. Setelah pemanasan selesai, sampel didinginkan, selanjutnya sampel dipindahkan ke dalam erlenmeyer dan ditambahkan 3 tetes indikator ferroin. Kemudian dilakukan titrasi dengan larutan FAS hingga terjadi perubahan warna dari biru kehijauan menjadi cokelat kemerahan dan volume FAS yang terpakai dicatat. Kadar COD dapat dihitung dengan persamaan berikut:

$\operatorname{COD}\left(\mathrm{mg} \mathrm{O}_{2} / \mathrm{L}\right)=\frac{(\mathrm{A}-\mathrm{B})_{\mathrm{x} M \mathrm{Mx} 8000}}{\mathrm{ml} \text { sampel }}$

Keterangan:

A = Volume FAS untuk blanko $(\mathrm{ml})$

$\mathrm{B}=$ Volume FAS untuk sampel $(\mathrm{ml})$

$\mathrm{M}=$ Molaritas FAS

$8000=$ Berat miliequivalent oksigen $\times 1000$ $\mathrm{ml} / \mathrm{L}$

\section{HASIL DAN PEMBAHASAN}

\section{Kerapatan Sel Mikroalga}

Berdasarkan hasil identifikasi mikroalga yang terdapat di dalam POME kolam IV PT. X yaitu Spirulina sp. sebagai mikroalga yang dominan, Chlorella pyrenoidosa, dan Chlamydomonas incerta. Kerapatan sel mikroalga pada penelitian ini dapat dilihat pada Gambar 2. Kerapatan sel mikroalga di awal kultivasi pada setiap flatfotobioreaktor dengan variasi periode pergantian limbah berturut-turut sebesar 2,$25 ; 2,34 ; 2,31$; dan 2,28 (x $10^{6} \mathrm{sel} / \mathrm{ml}$ ). Berdasarkan Gambar 2. terlihat bahwa kerapatan sel mikroalga dalam setiap perlakuan periode pergantian limbah berbeda-beda. Fase adaptasi tidak terlihat disetiap perlakuan, karena sel mikroalga yang dimasukkan kedalam tiap flatfotobioreaktor berasal dari kultur yang berada pada fase eksponensial sehingga sel mikroalga cepat dalam tumbuh dan membelah diri. Prihantini (2007) menyatakan bahwa fase adaptasi biasanya terjadi ketika inokulum yang diinokulasikan kedalam media baru yang berbeda komponen kimiawinya. Konsorsium mikroalga indigeneous tidak membutuhkan waktu adaptasi yang lama dalam pertumbuhannya, sehingga sel mikroalga akan cepat memasuki fase eksponensial (Nurhayati dkk, 2013).

Pertumbuhan sel mikroalga pada fase eksponensial ditandai dengan adanya peningkatan kerapatan sel dan terjadinya pembelahan sel yang tinggi. Peningkatan kerapatan sel disebabkan karena nutrisi yang tersedia dalam media kultur masih banyak sehingga pembelahan sel terjadi secara terus-menerus. Fase eksponensial tertinggi terdapat pada perlakuan pergantian limbah setiap 6 hari dengan kerapatan sel $1,01 \times 10^{7} \mathrm{sel} / \mathrm{ml}$ pada hari ke-12, diikuti oleh pergantian setiap 4 hari dan 3 hari dengan kerapatan sel 6,66 x 106 dan $5,31 \times 10^{6} \mathrm{sel} / \mathrm{ml}$. Hal ini terjadi karena sel-sel mikroalga memiliki waktu yang lebih lama untuk tumbuh, sehingga semakin lama interval pergantian limbah dalam sistem semikontinu, maka kerapatan sel akan semakin tinggi. Hasil penelitian ini sesuai dengan Chae dkk (2006), bahwa periode pergantian limbah pada kultur mikroalga Euglena gracilis yang semakin lama dari 3 hari menjadi 5 hari menyebabkan kerapatan sel meningkat dari $2 \times 10^{6} \mathrm{sel} / \mathrm{ml}$ menjadi $3 \times 10^{6} \mathrm{sel} / \mathrm{ml}$ pada akhir penelitian. 




(A)

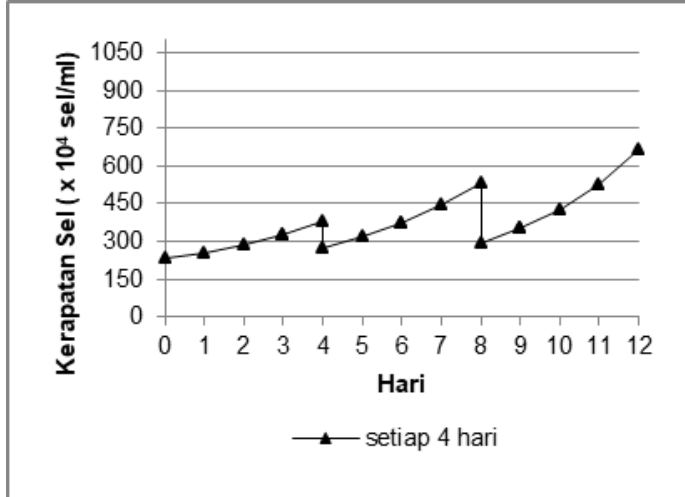

(C)

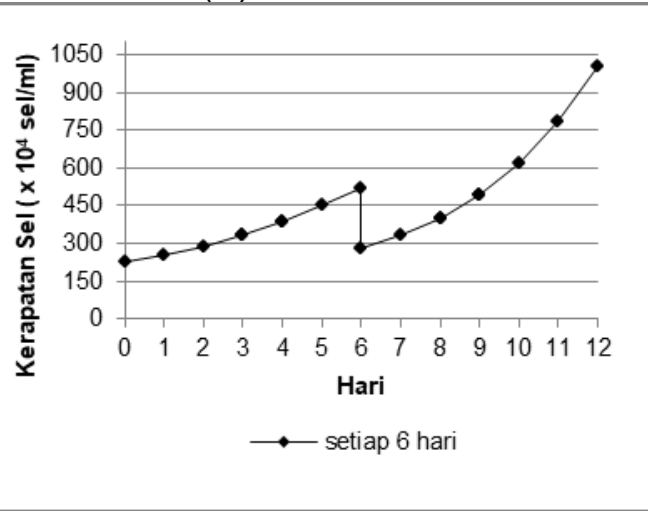

(D)

Gambar 2. Kerapatan Sel Mikroalga dengan Variasi Periode Pergantian Limbah (A) Kontrol (Batch) (B) Setiap 3 Hari (C) Setiap 4 Hari (D) Setiap 6 Hari

Pada perlakuan dengan adanya pergantian limbah, kerapatan sel akan terus naik menuju fase eksponensial tanpa mengalami fase penurunan laju pertumbuhan maupun fase kematian karena nutrisi untuk pertumbuhannya masih terpenuhi. Pada Gambar 2. dapat dilihat pula bahwa saat dilakukan pergantian limbah kerapatan sel menjadi menurun karena terjadinya pengenceran setelah ditambahkan medium baru. Selanjutnya kerapatan sel dan biomassa mikroalga akan meningkat kembali dan langsung memasuki fase eksponensial tanpa adanya fase lag. Fase eksponensial terendah terdapat pada perlakuan kontrol tanpa pergantian limbah (batch) dengan kerapatan sel $5,10 \times 10^{6} \mathrm{sel} / \mathrm{ml}$ pada hari ke-6 dan pada hari ke-7 telah memasuki fase penurunan laju pertumbuhan hingga kerapatan sel menurun menjadi 3,86 $\times 10^{6}$ $\mathrm{sel} / \mathrm{ml}$ pada hari ke-12. Hal ini terjadi karena nutrisi dalam medium yang semakin berkurang dan tidak adanya penambahan nutrien baru. Selain itu, peningkatan kerapatan sel dan biomassa pada fase eksponensial menyebabkan penetrasi cahaya yang masuk kedalam kultur semakin berkurang sehingga kerapatan sel akan semakin menurun.

\section{Kadar Lipid Konsorsium Mikroalga}

Hasil uji kadar lipid dengan variasi periode pergantian limbah dapat dilihat pada Gambar 3. Peningkatan kadar lipid dipengaruhi oleh beberapa faktor salah satunya nutrisi (Erlangga dkk, 2019). 


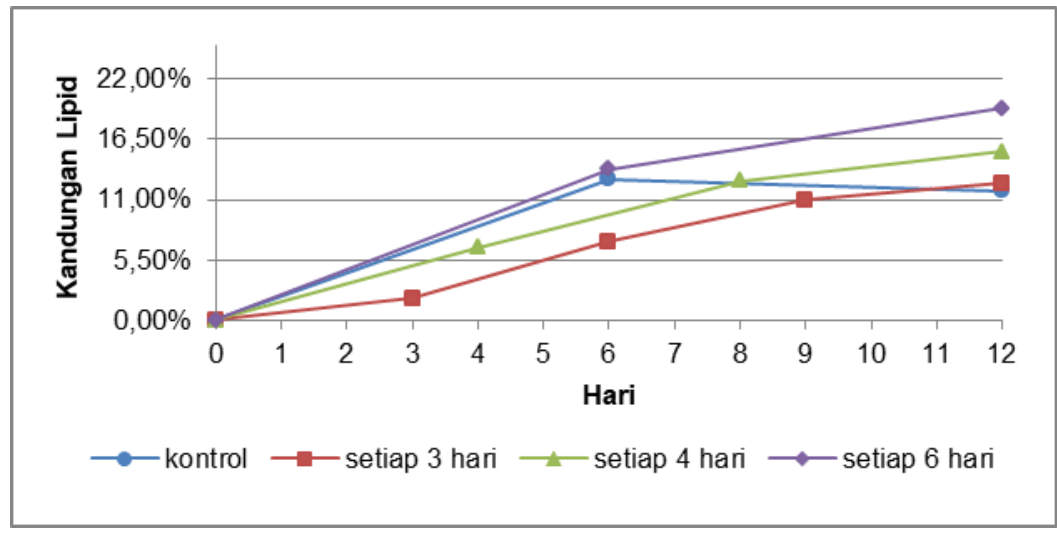

Gambar 3. Kadar Lipid Konsorsium Mikroalga

Berdasarkan Gambar 3. dapat dilihat kadar lipid tertinggi terdapat pada perlakuan pergantian limbah setiap 6 hari yaitu $19,33 \%$, sedangkan kadar lipid terendah terdapat pada perlakuan kontrol tanpa pergantian (batch) yaitu $11,82 \%$. Kadar lipid pada mikroalga selama proses kultivasi berbanding lurus dengan kerapatan sel dan biomassa mikroalga yang dihasilkan. Semakin lama interval waktu pergantian limbah maka pertumbuhan dan biomassa mikroalga meningkat karena nutrisi dalam pertumbuhannya terpenuhi, sehingga akumulasi kadar lipid dalam sel mikroalga akan semakin tinggi. Hal ini sesuai dengan yang dijelaskan Febtisuharsi (2016), bahwa tingginya kerapatan sel didalam medium akan sebanding dengan banyaknya lipid yang dihasilkan oleh mikroalga. Hubungan kadar lipid dan kerapatan sel dapat dilihat pada Gambar 4.

Berdasarkan Gambar 4. dapat dilihat bahwa pada awal kultivasi kadar lipid yang terdapat didalam mikroalga masih sangat rendah. Hal ini terjadi karena pada fase awal pertumbuhan mikroalga lebih banyak mensintesis protein untuk pertumbuhan dan perbanyakan sel (Bellou dan Aggelis, 2013). Sedangkan pada saat mencapai puncak fase eksponensial, kadar lipid didalam sel mikroalga akan mengalami peningkatan yang tinggi.

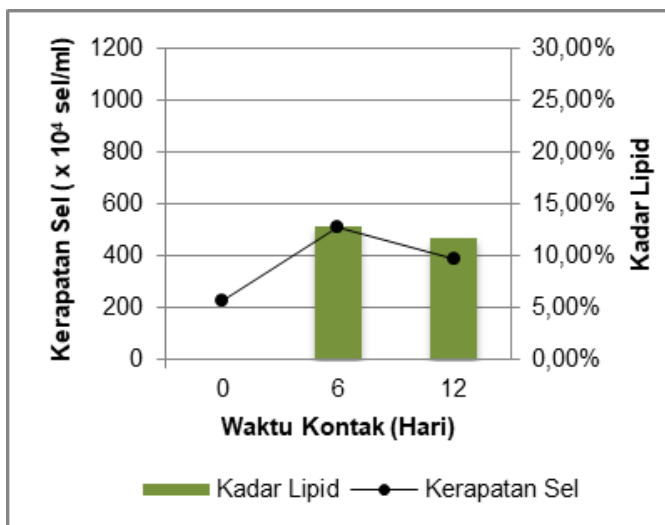

(A)

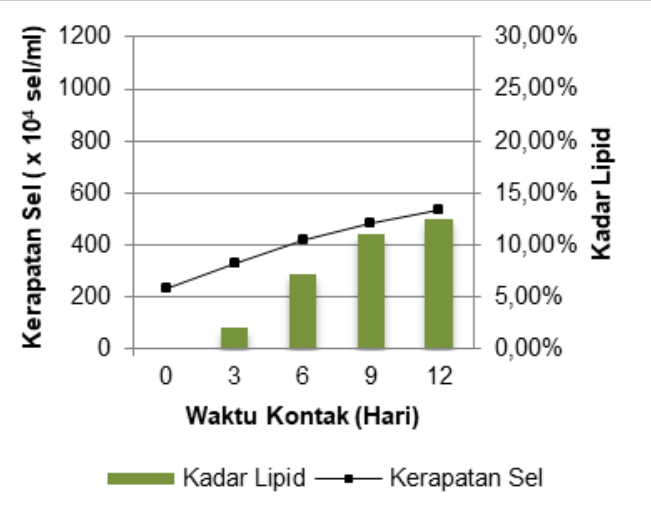

(B) 




(C)

(D)

Gambar 4. Hubungan Kerapatan Sel dan Kadar Lipid dengan Variasi Periode Pergantian Limbah (A) Kontrol (Batch) (B) Setiap 3 Hari

(C) Setiap 4 Hari (D) Setiap 6 Hari

Lipid disintesis dari protein dan karbohidrat berlebih yang dihasilkan oleh mikroalga pada saat proses fotosintesis dan terjadi didalam siklus krebs (Febtisuharsi, 2016). Pada proses fotosintesis $\mathrm{CO}_{2}$ akan diubah menjadi Glyceryde-3-Phosphate (G3P) yang digunakan sebagai perkusor dalam pembentukan karbohidrat dan lipid. Selanjutnya G3P diubah menjadi piruvat yang kemudian dikonversi menjadi acetylKoA dengan menggunakan enzim Pyruvate Dehydrogenase Complex (PDC). AcetylKoA merupakan prekusor untuk sintesis asam lemak. Reaksi pembentukan asam lemak terjadi pada plastida yang selanjutnya akan dibawa menuju retikulum endoplasma. Di retikulum endoplasma asam lemak akan diubah menjadi lipid struktural dan lipid non struktual. Transformasi molekul trigliserid menjadi lipid non struktural inilah yang akan menjadi molekul pembuatan biodiesel dalam proses transesterifikasi (Bellou dan Aggelis, 2013).
Perbandingan kadar lipid pada penelitian yang telah dilakukan sebelumnya dapat dilihat pada Tabel 1. Pada penelitian ini kadar lipid yang dihasilkan lebih tinggi dibandingkan dengan penelitian lainnya. Pada penelitian sebelumnya menggunakan konsorsium mikroalga campuran dan tidak berasal dari air limbah yang digunakan sebagai medium, sedangkan pada penelitian ini menggunakan konsorsium mikroalga indigeneous yang berasal dari air limbah yaitu POME. Konsorsium mikroalga indigeneous mudah beradaptasi dengan suhu dan lingkungannya serta pertumbuhannya lebih cepat dalam memasuki fase eksponensial, sehingga akumulasi kadar lipid didalamnya tidak membutuhkan waktu yang lama. Selain itu, lebih menghemat biaya pada proses kultivasinya karena dapat memanfaatkan mikroalga yang terdapat dalam air limbah sebagai bahan baku biofuel.

Tabel 1. Kadar Lipid Mikroalga pada Kondisi Kultivasi yang Berbeda

\begin{tabular}{ccccc}
\hline No. & Mikroalga & $\begin{array}{c}\text { Limbah yang } \\
\text { Digunakan }\end{array}$ & $\begin{array}{c}\text { Kadar Lipid } \\
(\%)\end{array}$ & Referensi \\
\hline 1. & $\begin{array}{c}\text { Konsorsium } \\
\text { mikroalga }\end{array}$ & $\begin{array}{c}\text { Limbah cair industri } \\
\text { karpet }\end{array}$ & 6,82 & Chinnasamy dkk, 2010 \\
2. & $\begin{array}{c}\text { Konsorsium } \\
\text { mikroalga }\end{array}$ & $\begin{array}{c}\text { Limbah cair rumah } \\
\text { pemotongan hewan } \\
\text { Limbah cair artificial }\end{array}$ & 3,03 & Rahmasari, 2010 \\
3. & $\begin{array}{c}\text { Konsorsium } \\
\text { mikroalga } \\
\text { Konsorsium } \\
\text { mikroalga } \\
\text { indigeneous }\end{array}$ & POME & 10 & Kyle dan Wudneh, 2012 \\
& & 19,33 & Penelitian ini, 2019 \\
\hline
\end{tabular}




\section{Penurunan Kadar COD}

Pada penelitian ini POME digunakan sebagai medium pertumbuhan dan nutrisi bagi mikroalga, selain itu dapat menurunkan kadar COD yang terkandung didalam POME (Istirokhatun dkk, 2017). Hasil uji kadar COD dan efisiensi penyisihan COD pada penelitian ini dapat dilihat pada Gambar 5. dan Gambar 6.

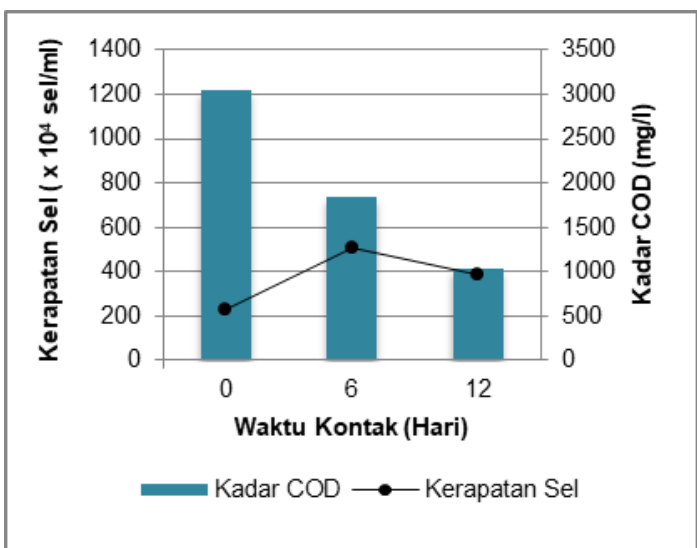

(A)

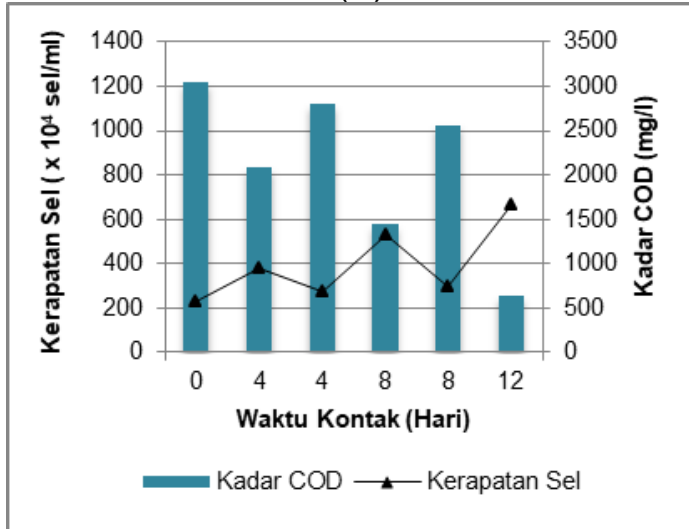

(C)

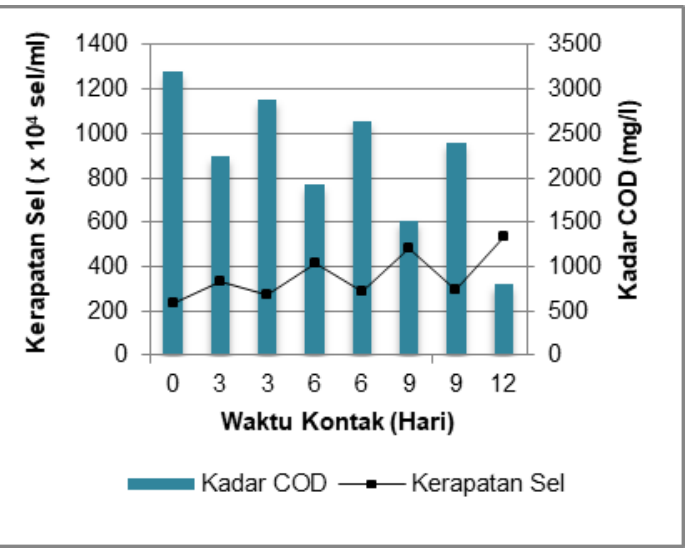

(B)

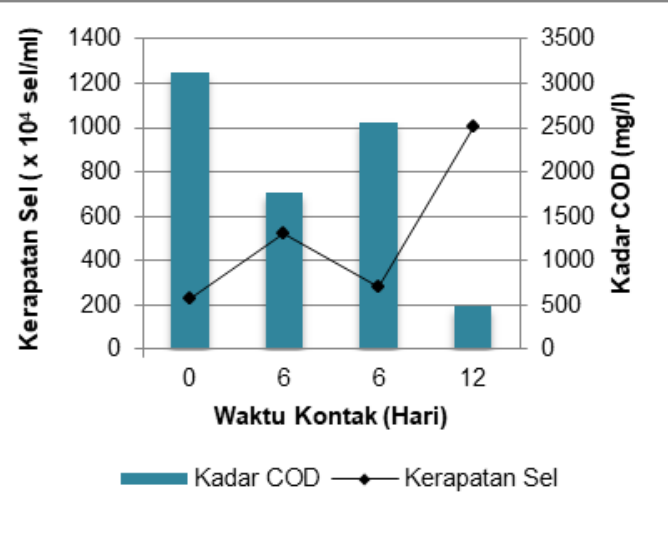

(D)

Gambar 5. Hubungan Kerapatan Sel dan Kadar COD dengan Variasi Periode Pergantian Limbah (A) Kontrol (Batch) (B) Setiap 3 Hari

(C) Setiap 4 Hari (D) Setiap 6 Hari

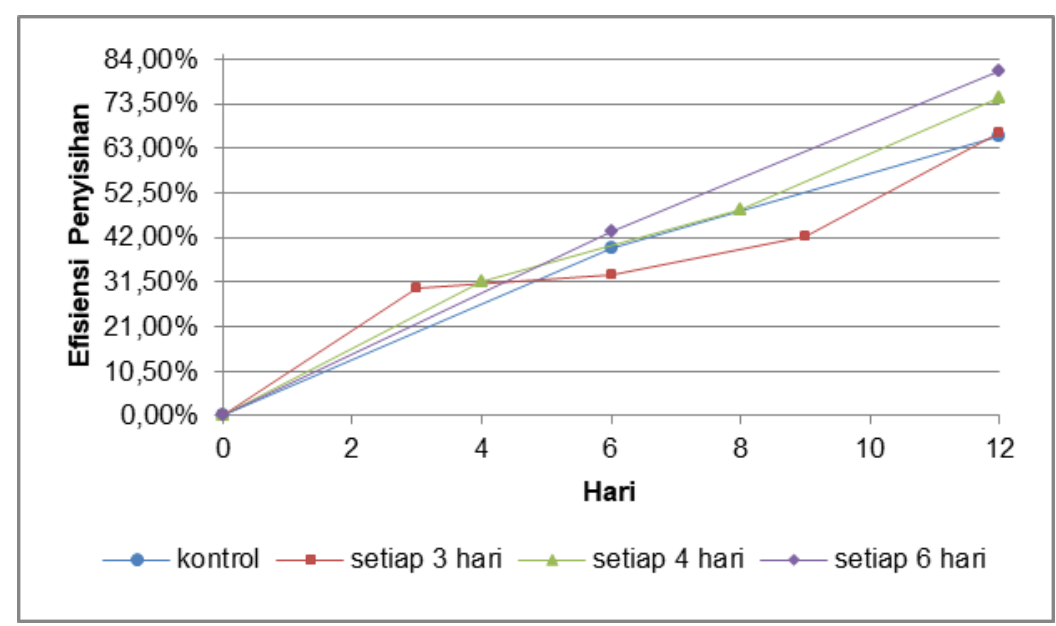

Gambar 6. Efisiensi Penyisihan COD

Berdasarkan Gambar 5. menunjukkan bahwa kadar COD dalam POME menurun selama 12 hari. Penyisihan COD tertinggi pada penelitian ini terjadi pada perlakuan Jurnal Sains dan Teknologi | 35 
pergantian limbah setiap 6 hari sebesar $81,25 \%$ dengan kadar COD awal 3.120 $\mathrm{mg} / \mathrm{l}$ menjadi $480 \mathrm{mg} / \mathrm{l}$ pada hari ke-12. Hal ini dikarenakan semakin lama waktu pergantian limbah maka semakin banyak nutrisi dalam POME yang diserap oleh mikroalga sehingga kerapatan sel meningkat dan kadar COD pada POME semakin berkurang. Hal ini sesuai dengan penelitian Anbalagan dkk (2016), bahwa penurunan kadar COD tertinggi terjadi pada periode pergantian limbah setiap 6 hari dengan kadar COD 275,4 mg/l dibandingkan dengan 3 hari, dengan kerapatan sel dan biomassa yang dihasilkan juga lebih tinggi sehingga penyisihan COD lebih meningkat. Penyisihan terendah terjadi pada perlakuan kontrol tanpa pergantian limbah (batch) sebesar 65,79\% dengan kadar COD akhir $1040 \mathrm{mg} / \mathrm{l}$ pada hari ke-12.

Jika dibandingkan dengan pertumbuhan sel mikroalga, didapatkan hasil penelitian bahwa kerapatan sel berbanding lurus dengan penurunan kadar COD yang ada didalam POME. Hal ini dikarenakan sel-sel mikroalga tumbuh dengan menyerap zat-zat organik sebagai nutrisi untuk pertumbuhannya. Hasil ini sesuai dengan penelitian Malla dkk (2015), yang menunjukkan bahwa semakin tinggi kerapatan sel mikroalga maka penurunan kadar COD (Chemical Oxygen Demand) akan semakin baik.

Penurunan kadar COD terjadi karena adanya proses oksidasi yang dilakukan oleh bakteri. Adanya simbiosis antara mikroalga dan bakteri dalam proses metabolismenya dapat mengubah bahan organik kompleks didalam limbah menjadi bahan organik sederhana yang kemudian dapat diserap oleh mikroalga dalam proses fotosintesis (Aslan dan Kapdan, 2006). Perbandingan efisiensi penyisihan COD oleh mikroalga pada penelitian lainnya dapat dilihat pada Tabel 2 .

Tabel 2. Perbandingan Efisiensi Penyisihan COD pada Penelitian Lainnya

\begin{tabular}{ccccc}
\hline No. & Mikroalga & $\begin{array}{c}\text { Limbah yang } \\
\text { Digunakan }\end{array}$ & Efisiensi (\%) & Referensi \\
\hline 1. & $\begin{array}{c}\text { Konsorsium } \\
\text { mikroalga }\end{array}$ & $\begin{array}{c}\text { Limbah cair } \\
\text { peternakan }\end{array}$ & 78 & Manalu, 2010 \\
2. & $\begin{array}{c}\text { Konsorsium } \\
\text { mikroalga }\end{array}$ & $\begin{array}{c}\text { Limbah cair rumah } \\
\text { pemotongan hewan } \\
\text { Limbah cair susu }\end{array}$ & 50 & Rahmasari, 2010 \\
2. & $\begin{array}{c}\text { Konsorsium } \\
\text { mikroalga } \\
\text { Konsorsium } \\
\text { mikroalga } \\
\text { indigeneous }\end{array}$ & POME & 81,25 & Qin dkk, 2016 \\
\hline
\end{tabular}

Berdasarkan Tabel 2 dapat dilihat bahwa pada penelitian ini didapatkan efisiensi penyisihan COD yang lebih tinggi dibandingkan dengan penelitian yang lainnya dikarenakan perbedaan asal mikroalga yang digunakan dalam pengolahan air limbah. Manalu (2010) dan Rahmasari (2010) melakukan penelitian dengan menggunakan konsorsium mikroalga yang berasal dari Danau LSI IPB. Penelitian yang dilakukan oleh Qin dkk (2016) menggunakan mikroalga campuran yang terdiri dari Chlorella sp., Scenedesmus sp., dan C. zofingiensis. Ketiga penelitian ini tidak menggunakan mikroalga indigeneous dari air limbah, sedangkan pada penelitian ini digunakan konsorsium mikroalga indigeneous dari air limbah yang digunakan yaitu POME. Konsorsium mikroalga indigeneous yang digunakan cepat beradaptasi dengan mediumnya dan langsung memasuki fase eksponensial sehingga kerapatan sel dan efisiensi penyisihan COD yang dihasilkan lebih tinggi.

\section{SIMPULAN}

Dari penelitian yang telah dilakukan dapat ditarik kesimpulan sebagai berikut: 
1. Kultivasi pada medium POME dengan variasi periode pergantian limbah memberikan pengaruh terhadap kerapatan sel, kadar lipid, dan penyisihan COD konsorsium mikroalga yang dihasilkan dengan hasil tertinggi terdapat pada perlakuan pergantian limbah setiap 6 hari berturut-turut sebesar 1,01 x 107 $\mathrm{sel} / \mathrm{ml}, 19,33 \%$ dan $81,25 \%$.

2. Sistem semikontinu dengan adanya pergantian limbah dapat meningkatkan kerapatan sel mikroalga karena nutrisi dalam medium kultur terpenuhi, sehingga kadar lipid dan efisiensi penyisihan COD yang dihasilkan akan semakin meningkat.

\section{UCAPAN TERIMAKASIH}

Terima kasih penulis ucapkan kepada Laboratorium Pengendalian dan Pencemaran Lingkungan, Fakultas Teknik, Universitas Riau dan Pusat Penelitian Alga, Fakultas Perikanan dan IImu Kelautan, Universitas Riau serta semua semua pihak yang telah memberikan bantuan dalam menyelesaikan penelitian ini.

\section{DAFTAR PUSTAKA}

Abomohra A.E. F., Jin W, Tu R, Han S. F., Eid M., Eladel H. 2016. Microalgal Biomass Production as a Sustainable Feedstock for Biodiesel: Current Status and Perspectives. Renew Sustain Energy Rev. 64: 596-606.

Anbalagan, A., Sebastian, S.,Carl, F. L., dan Emma, N. 2016. Influence of Hydraulic Retention Time on Indigenous Microalgae and Activated Sludge Process. Water Research. 91: 277-284.

Aslan S. dan Kapdan, I. K. 2006. Batch Kinetics of Nitrogen and Phosphorous Removal from Synthetic Wastewater by Algae. Ecological Engineering. 28: 64-70.

Badan Pusat Statistik (BPS). 2017. Neraca Energi Indonesia 2012-2016.

Bastidas, O. 2008. Thoma Chamber Formulae Calculation with Thoma Chamber Made Easy. Celeromic.
Bellou, S. dan Aggelis G. 2013. Biochemical Activities in Chlorella sp. and Nannochloropsis salina During Lipid and Sugar Synthesis in a LabScale Open Pond Simulating Reactor. Journal of Biotechnology. 1: 1-12.

Budianta, D. 2005. Potensi Limbah Cair Pabrik Kelapa Sawit Sebagai Sumber Hara Untuk Tanaman Perkebunan. Jurnal Dinamika Pertanian. 20(3): 273282.

Chae, S. R., E. J. Hwang, dan H. S. Shin. 2006. Single Cell Protein Production of Euglena Gracilis and Carbon Dioxide Fixation in an Innovative PhotoBioreactor. Biores Technol. 97: 322329.

Cheah, W. Y., Tau, C. L., Pau, L. S., Joon, C. J., Jo, S. C., dan Duu J. L. 2016. Cultivation in Wastewaters for Energy:

A Microalgae Platform. Applied Energy. 179: 609-625.

Chinnasamy, S., Bhatnagar, A., Hunt, R.W., dan Das, K. C. 2010. Microalgae Cultivation in a Wastewater Dominated by Carpet Mill Effluents for Biofuel Applications. Bioresour Technol. 101(9): 3097-3105.

Chisti, Y. 2007. Biodiesel from Microalgae. Biotechnology Advances. 25: 294-306.

Erlangga, H. F. 2019. Pemanfaatan Chlorella pyrenoidosa sebagai Bahan Baku Biofuel dengan Memanfaatkan Kandungan Nutrisi pada Palm Oil Mill Effluent (POME). Skripsi. Fakultas Teknik Universitas Riau.

Febtisuharsi, A. 2016. Kepadatan sel dan Kadar Lipid Mikroalga Chlorella sp. pada Kultur Media Alternatif Kotoran Ternak. Skripsi. Fakultas Matematika dan IImu Pengetahuan Alam Universitas Negeri Semarang.

Hadiyanto dan Maulana A. 2012. Mikroalga Sumber Pangan dan Energi Masa Depan Edisi Pertama. Semarang: UPT UNDIP Press.

Hena, S., Fatimah, S., dan Tabassum, S. 2015. Cultivation of Algae Consortium in a Dairy Farm Wastewater for Biodiesel Production. Water Resources and Industry. 10: 1-14.

Hossain, ABMS, Salleh, A., Boyce, A.N., Chowdhury, P., dan Naqiuddin M. 
2008. Biodiesel Fuel Production from Algae as Renewable Energy American. Journal of Biochemistry and Biotechnology. 4(3): 250-254.

Istirokhatun, T., Mustika, A., dan Sudarno. 2017. Potensi Chlorella sp. untuk Menyisihkan COD dan Nitrat dalam Limbah Cair Tahu. Jurnal Presipitasi : Media Komunikasi dan Pengembangan Teknik Lingkungan. 14(2).

Kim, B. H., Zion, K., Rishiram, R., Jong, E. C., Dae, H. C., Hee, M. O., dan Hee, S. K. 2014. Nutrient Removal and Biofuel Production in High Rate Algal Pond Using Real Municipal Wastewater. J. Microbiol Biotechnol. 24(8): 1123-1132.

Kyle R. J. dan Wudneh A. 2012. Mixed Algae Cultures for Low Cost Environmental Compensation in Cultures Grown for Lipid Production and Wastewater Remediation. Journal Chem Technol Biotechnol. 88: 992998.

Mahdi, M. Z., Titisari, Y. N., dan Hadiyanto. 2012. Evaluasi Pertumbuhan Mikroalga dalam Medium POME: Variasi Jenis Mikroalga, Medium dan Waktu Penambahan Nutrien. Jurnal Teknik Kimia dan Industri. 1(1): 312319.

Malla, F.A., Khan, S.A., Rashmi., Sharma, G.K., Gupta, N., dan Abraham, G. 2015. Phycoremediation Potential of Chlorella minutissima on Primary and Tertiary Treated Wastewater for Nutrient Removal and Biodiesel Production. Ecological Engineering. 75: 343-349.

Manalu, S. 2010. Karakterisasi Pertumbuhan Mikroalga dan Eliminasi Nutrien Dari Limbah Cair Peternakan dengan Sistem Semikontinu. Skripsi. Fakultas Teknologi Pertanian Institut Pertanian Bogor.

Mata, T. M., Antonio, A. M., dan Nidia, S. C. 2010. Microalgae for Biodiesel Production and Other Applications: A Review. Renew Sustain Energy Rev. 14: 217-32.

Nurhayati, C., Basuni, H., dan Rindit, P. 2013. Optimasi Pengolahan Limbah
Cair Karet Remah Menggunakan Mikroalga Indigen dalam Menurunkan Kadar BOD, COD, TSS. Jurnal Dinamika Penelitian Industri. 24(1): 16 $-26$.

Prihantini, N. B., Dini D., dan Ratna, Y. 2007. Pengaruh Konsentrasi Medium Ekstrak Tauge (MET) Terhadap Pertumbuhan Scenedesmus Isolat Subang. Makara Sains. 11(1): 1-9.

PT. X. 2019. Hasil Pengujian Kualitas Air Kolam IPAL No. IV - LA.

Putri, L. R., Agus, S., dan Joni, H. 2014. Pengaruh Penambahan Glukosa Sebagai Co-substrate dalam Pengolahan Air Limbah Minyak Solar Menggunakan Sistem High Rate Alga Reactor (HRAR). Jurnal Teknik POMITS. 3(2): 2337-3539.

Qin, L., Wang, Z., Sun, Y., Shu, Q., Feng, P., Zhu, L., Xu, J., dan Yuan, Z. 2016. Microalgae Consortia Cultivation in Dairy Wastewater to Improve The Potential of Nutrient Removal and Biodiesel Feedstock Production. Environ Sci Pollut Res Int. 23(9): 8379-8387.

Rahmasari, W. J. 2010. Karakterisasi Pertumbuhan Mikroalga dan Penyisihan Nutrien dari Limbah Cair Rumah Potong Hewan dengan Sitem Kultur Semikontinu. Skripsi. Fakultas Teknologi Pertanian Institut Pertanian Bogor.

Spolaore, P., Joannis, C. C., Duran, E., dan Isambert, A. 2006. Commercial Applications of Microalgae. Journal of Bioscience and Bioenginering. 101: 87-96.

Suantika, G. dan Deri, H. 2009. Efektivitas Teknik Kultur menggunakan Sistem Kultur Statis, Semikontinu, dan Kontinu Terhadap Produktivitas dan Kualitas Kultur Spirulina sp. Jurnal Matematika dan Sains. 14(2).

Woertz, I., A. Feffer, T. Lundquist, dan Y. Nelson. 2009. Algae Grown on Dairy and Municipal Wastewater for Simultaneous Nutrient Removal and Lipid Production for Biofuel Feedstock. Journal of Environmental EngineeringAsce. 135(11): 1115-1122. 
Yang, Y. C., Jhong, F. J., Chiu, M. K., Wen, X. Z., dan Chih, S. L. 2017. Biomass and Lipid Production of Chlorella sp. Using Municipal Wastewater Under Semicontinuous Cultivation. International Proceedings of Chemical Biological and Environmental Engineering. 101. 